\title{
ARTICLE \\ Effects of ionic composition on growth and survival of white shrimp Litopenaeus vannamei culture at low-salinity well water
}

Efecto de la composición iónica sobre el crecimiento y la supervivencia de camarón blanco Litopenaeus vannamei cultivado en agua de pozo de baja salinidad

\section{Ismael E. Valenzuela-Madrigal ${ }^{1}$, Wenceslao Valenzuela-Quiñónez ${ }^{2 *}$, Héctor M. Esparza-Leal $^{2}$, Gerardo Rodríguez-Quiroz ${ }^{2}$ and E. Alberto Aragón-Noriega ${ }^{3}$}

\begin{abstract}
${ }^{1}$ Maestría en Recursos Naturales y Medio Ambiente Program Student, Instituto Politécnico Nacional-CIIDIR Unidad Sinaloa, México. ${ }^{2}$ Instituto Politécnico Nacional-CIIDIR Unidad Sinaloa, Departamento de Acuacultura, Boulevard Juan de Dios Batís Paredes \# 250, Guasave, Sinaloa 81101, México. wvalenzuela@ipn.mx

${ }^{3}$ Centro de Investigaciones Biológicas del Noroeste, Unidad Sonora. Km 2.35 Camino al Tular, Estero Bacochibampo, Guaymas, Sonora 85454, México

Resumen.- El cultivo de camarón blanco Litopenaeus vannamei en agua con baja salinidad $\left(1,2 \pm 0,5 \mathrm{~g} \mathrm{~L}^{-1}\right)$ y con diferente composición iónica afecta el desempeño de los organismos en cultivo. El efecto de cultivar en agua de baja salinidad con diferente contenido de iones fue evaluado en crecimiento y supervivencia del camarón. Cuatro pozos de diferente composición iónica del agua fueron seleccionados en el Río Sinaloa, Guasave, México, localizados en: $\left(T_{1}\right) 25,43^{\circ} \mathrm{N}, 108,44^{\circ} \mathrm{W} ;\left(T_{2}\right) 25,48^{\circ} \mathrm{N}$, $108,37^{\circ} \mathrm{W} ;\left(T_{3}\right) 25,60^{\circ} \mathrm{N}, 108,40^{\circ} \mathrm{W}$ y $\left(T_{4}\right) 25,64^{\circ} \mathrm{N}, 108,51^{\circ} \mathrm{W}$. El diseño experimental fueron 4 tratamientos con 3 réplicas. También se cultivó camarón en agua de mar $\left(\mathrm{T}_{\mathrm{m}}=34 \pm 1,4 \mathrm{~g} \mathrm{~L}^{-1}\right)$ como control. El camarón cultivado en $\mathrm{T}_{\mathrm{m}}$ y $\mathrm{T}_{1}$ alcanzaron peso promedio superior a $12 \mathrm{~g}$ y tasa de supervivencia del $78 \%$, con diferencias significativas a los demás tratamientos de agua de baja salinidad. El factor de condición obtenida con agua de baja salinidad $\left(T_{1}=0,654\right)$ fue similar al registrado para $T_{m}(0,670)$, donde las proporciones iónicas $(\mathrm{Na} / \mathrm{K}$ y $\mathrm{Mg} / \mathrm{K})$ fueron similares en ambos. Esta última observación sugiere que las proporciones de los principales iones $\left(\mathrm{Na}^{+}, \mathrm{K}^{+}, \mathrm{Mg}^{2+}\right.$ y Ca $\left.{ }^{2+}\right)$ juegan un papel relevante para el desarrollo de los organismos bajo cultivo. Cuando la relación iónica fue similar a la del agua de mar, se obtuvieron organismos con el mejor desarrollo, indicando que la proporción de iones mayores fueron importantes para el crecimiento y desempeño del camarón en cultivo.
\end{abstract}

Palabras clave: Litopenaeus vannamei, composición iónica, agua de pozo de baja salinidad

\begin{abstract}
The culture of white shrimp Litopenaeus vannamei in low salinity waters $\left(1.2 \pm 0.5 \mathrm{~g} \mathrm{~L}^{-1}\right)$ presents challenges, the deviation of the ionic composition of water is known that influences the overall condition of the cultured organisms. The effect of water of low salinity with different ion content on the growth and survival of shrimp was determined. First, water was extracted from 4 wells with a depth of 5 to $7 \mathrm{~m}$, located in Sinaloa River Basin in Guasave, Mexico at: $\left(T_{1}\right) 25.43^{\circ} \mathrm{N}, 108.44^{\circ} \mathrm{W} ;\left(T_{2}\right) 25.48^{\circ} \mathrm{N}$, $108.37^{\circ} \mathrm{W} ;\left(T_{3}\right) 25.60^{\circ} \mathrm{N}, 108.40^{\circ} \mathrm{W}$ and $\left(T_{4}\right) 25.64^{\circ} \mathrm{N}, 108.51^{\circ} \mathrm{W}$ and were selected on base the different ionic water composition. The experimental design was 4 independent treatments with 3 replicate. Shrimp were grown at sea water $\left(\mathrm{T}_{\mathrm{m}}=34 \pm 1.4 \mathrm{~g} \mathrm{~L}^{-1}\right)$ used as a control. Shrimps grown in $T_{m}$ and $T_{1}$ had averaged weight (over $12 \pm 0.61 \mathrm{~g}$ ) and survival rates $(78 \%$ ), with statistical differences to others low salinity water treatments. The condition factor obtained with low-salinity water $\left(T_{1}=0.654\right)$ was like that recorded for $T_{m}(0.670)$, where ionic ratios $(\mathrm{Na} / \mathrm{K}$ and $\mathrm{Mg} / \mathrm{K})$ were similar to that of seawater. This observation strongly suggests that the ratios of the major ions $\left(\mathrm{Na}^{+}, \mathrm{K}^{+}, \mathrm{Mg}^{2+}\right.$ and $\left.\mathrm{Ca}^{2+}\right)$ play a relevant role for development of organisms under cultivation. Shrimp cultured in water of low salinity with an ionic ratio similar to that of sea water were organisms with the best development under cultivation, therefore indicating that the proportion of major ions were important for shrimp.
\end{abstract}

Key words: Litopenaeus vannamei, ionic composition, low-salinity well water

\section{INTRODUCTION}

In order to optimize the shrimp culture with water of low salinity is necessary to assess the impact of the variability in the ionic composition of water on the general condition of the organisms (Gong et al. 2004, Gullian et al. 2010). The shrimp industry in the United States of America (Roy et al. 2010), Brazil (Nunes
\& Lopez 2001), Thailand (Saoud et al. 2003, Roy et al. 2007), China (Cheng et al. 2005) and Mexico (Godinez-Siordia et al. 2011), advanced the cultivation of Litopenaeus vannamei (Boone, 1931) in water with salinities less than $5 \mathrm{~g} \mathrm{~L}^{-1}$. However, still lack of information regarding the condition and survival of 
the shrimp L. vannamei in a full cycle culture, in response to growing with well water or surface water with low salinity and different ion profile (Gullian et al. 2010). Shrimp aquaculture presents challenges such as determining how water ionic conditions limit productive potential of shrimp species in each farm regions.

The ionic composition and salinity of water can vary widely between sites, so in some regions, natural sources of low-salinity water cannot be used directly for shrimp culture (Davis et al. 2002, Saoud et al. 2003, Zhu et al. 2006). In some cases, there are low levels of potassium, magnesium and other ions, or deviations in the proportions of the ionic compositions, which limit the development of shrimp crops. The ions (calcium, sodium, potassium and chloride) play a basic role in the osmoregulatory process and intervene on the maintenance of membrane potentials (Mantel \& Farmer 1983, Pequeux 1995). Shrimp require minerals to maintain basal metabolism and growth. Soluble minerals are constituents of tissues, enzymatic cofactors and play a role in metabolism of lipids, proteins and carbohydrates (Davis \& Lawrence 1997) and, the same authors, suggested to add as dietary supplements in shrimp reared in low salinity water.

It has been experimentally determined that when there is a deviation in the concentration of essential ions in relation to those found in seawater, such as $\mathrm{K}^{+}$and $\mathrm{Mg}^{2+}$, growth and survival of L. vannamei in both acclimation (Saoud et al. 2003) and growing (Samocha et al. 2004) conditions are limited. Boyd (1989) reported that salinities between 15 and $25 \mathrm{~g} \mathrm{~L}^{-1}$ are ideal for growing white shrimp L. vannamei, whilst Samocha et al. (2004) reported that cultivating this species in low salinity water $\left(<3 \mathrm{~g} \mathrm{~L}^{-1}\right)$ could support growths up to $14 \mathrm{~g}$.

Condition factor resultant of the potential equation parameters (Araneda et al. 2008) provide an evaluation of the specific conditions under which organisms are developing and can be valuable to culture system management because differently factors can affect isometry. Last, interpreted like equality of growth rates in two parts in the growth stage organisms (Chow \& Sandifer 1991). The condition factor (CF) determined from Fulton's equation (Ricker 1979, Chow \& Sandifer 1991) to evaluate the effect on a specific characteristic in which shrimp farming developed. The proportionality of length $(\mathrm{cm})$ and weight (g) were tested in the juvenile growing shrimp. Alteration in the expected relationship of isometric growth $(b=3)$ may be usually considered as an indicator of change in the physical or physiological well-being of the individuals under study. When this relationship is diverted to the allometric growth $(b<3)$, the physiological status could be interpreted as negative (Pauly 1984), because that population is tend to maintain a slower growth, smaller size, lower survival and hence low productive performance. Positive allometric $(b>3)$ organisms have the added advantage of growing more in weight than in length (Araneda et al. 2008).

The objective of this research was to determine the effect of 4 sources of well water of low salinity with different ionic composition on growth, survival and condition factor $(\mathrm{CF})$ of juvenile marine shrimp L. vannamei cultured at high density.

\section{MATERIALS AND METHODS}

\section{ORIGIN OF WATER USED IN THE EXPERIMENTAL WORK}

The experimental work was performed using 4 sources of well water with low salinity and different ionic composition. The water was extracted from 4 wells with a depth of 5 to $7 \mathrm{~m}$, which were located in Sinaloa River Basin (25.3-26.5 ${ }^{\circ} \mathrm{N}$, 106.7$108.5^{\circ} \mathrm{W}$ ) in Guasave, Mexico. The wells are located at the following coordinates (i) 1 to 4 (Ti): ( $\left.\mathrm{T}_{1}\right) 25.43^{\circ} \mathrm{N}, 108.44^{\circ} \mathrm{W}$; $\left(\mathrm{T}_{2}\right) 25.48^{\circ} \mathrm{N}, 108.37^{\circ} \mathrm{W} ;\left(\mathrm{T}_{3}\right) 25.60^{\circ} \mathrm{N}, 108.40^{\circ} \mathrm{W}$ and $\left(\mathrm{T}_{4}\right)$ $25.64^{\circ} \mathrm{N}, 108.51^{\circ} \mathrm{W}$.

\section{EXPERIMENTAL DESIGN}

The experimental work was designed to compare the effect of the ionic composition of different sources of well water on productive parameters and condition factor $(\mathrm{CF})$ of juvenile marine shrimp Litopenaeus vannamei, stocked at a density of 150 organism $\mathrm{m}^{-2}$. The culture was conducted in a greenhouse in 15 fiberglass containers $(1 \mathrm{~m} \mathrm{x} 1 \mathrm{~m} \times 1 \mathrm{~m})$. Treatments $\left(\mathrm{T}_{1}, \mathrm{~T}_{2}\right.$, $\mathrm{T}_{3}$ and $\mathrm{T}_{4}$ ) and the control group ( $\mathrm{T}_{\mathrm{m}}$ ) each with 3 replicates operated as separate systems. In the $\mathrm{T}_{\mathrm{m}}$ shrimp was grown using seawater $\left(34.0 \pm 0.5 \mathrm{~g} \mathrm{~L}^{-1}\right)$ under the same conditions of treatment with well water. To maintain the water quality each experimental unit received a daily water exchange of $10 \%$. The shrimp are grown in natural photoperiods ( $14 \mathrm{~h}$ light $/ 10 \mathrm{~h}$ dark). Each of the containers was maintained with constant aeration to meet dissolved oxygen (DO) requirements $\left(4-5 \mathrm{mg} \mathrm{L}^{-1}\right)$.

\section{Maintenance, Stocking AND REaring OF EXPERIMENTAL ORGANISMS}

A single batch of shrimp postlarvae L. vannamei $\left(\mathrm{PL}_{20}\right)$ was obtained from a commercial laboratory and stocked in a fiberglass $\operatorname{tank}(2,600 \mathrm{~L})$; they remained for 3 days at a salinity of $34 \pm 0.5 \mathrm{~g} \mathrm{~L}^{-1}$, with constant water flow $\left(0.6 \mathrm{~L} \mathrm{~min}^{-1}\right)$ and aeration. Prior to the start of the experiment, shrimp were acclimated from seawater $\left(34.0 \pm 0.5 \mathrm{~g} \mathrm{~L}^{-1}\right)$ until to reach to the salinity of each of the respective wells (Fig. 1, Table 1) with a rate of change of $0.25 \mathrm{~g} \mathrm{~L}^{-1} \mathrm{~h}$ (McGraw \& Scarpa 2004, Esparza-Leal et al. 2010). Subsequently, the shrimp postlarvae $(0.012 \pm 0.004 \mathrm{~g})$ were stocked into tanks. 

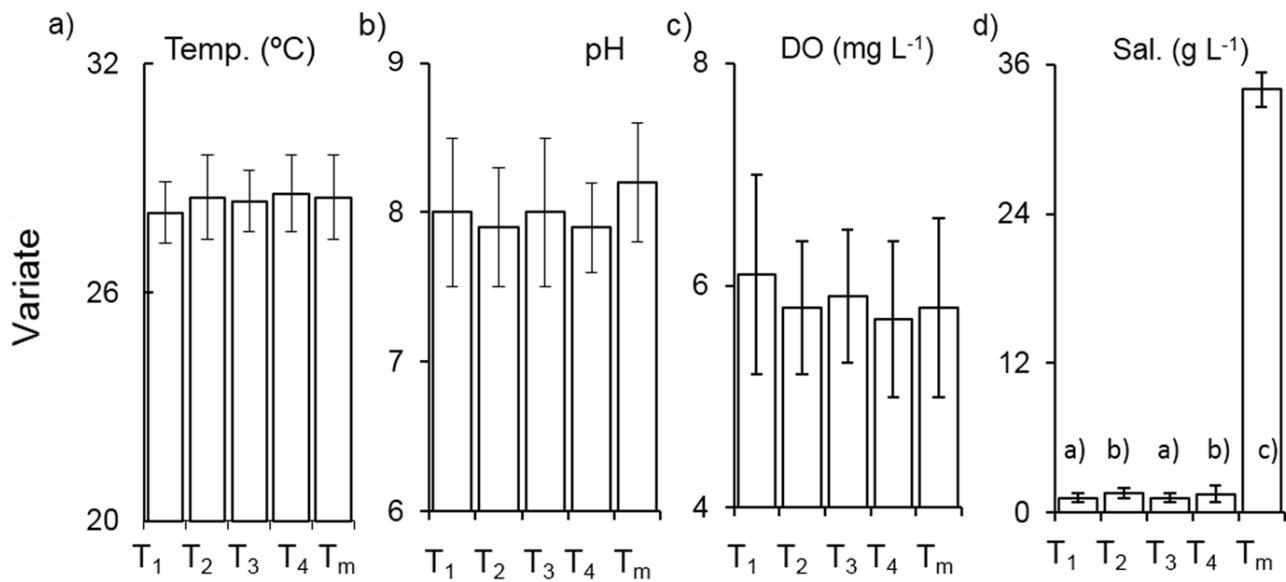

Treatment

Figure 1. M eans $( \pm S D)$ of water parameters from different sources of low salinity well water and seawater (control) throughout culture period. Water sources: $\left(T_{1}\right) 25.43^{\circ} \mathrm{N}, 108.44^{\circ} \mathrm{W} ;\left(T_{2}\right) 25.48^{\circ} \mathrm{N}, 108.37^{\circ} \mathrm{W} ;\left(T_{3}\right) 25.60^{\circ} \mathrm{N}, 108.40^{\circ} \mathrm{W} ;\left(T_{4}\right) 25.64^{\circ} \mathrm{N}, 108.51^{\circ} \mathrm{W}$ and $\mathrm{T}_{\mathrm{m}}$, seawater at $25.303^{\circ} \mathrm{N}, 108.533^{\circ} \mathrm{W} /$ Medias ( $\pm \mathrm{DE}$ ) de los parámetros de agua de pozo con baja salinidad de diferente origen y del agua de mar (control) a lo largo período de cultivo. Los pozos de agua se localizaron: $\left(T_{1}\right) 25,43^{\circ} \mathrm{N}, 108,44^{\circ} \mathrm{O} ;\left(\mathrm{T}_{2}\right) 25,48^{\circ} \mathrm{N}, 108,37^{\circ} \mathrm{O} ;\left(\mathrm{T}_{3}\right) 25,60^{\circ} \mathrm{N}, 108,40^{\circ} \mathrm{O} ;\left(\mathrm{T}_{4}\right)$ $25,64^{\circ} \mathrm{N}, 108,51^{\circ} \mathrm{O}$ y $\left(\mathrm{T}_{\mathrm{m}}\right)$ agua de mar en $25,303^{\circ} \mathrm{N}, 108,533^{\circ} \mathrm{O}$

Table 1. Mean ( \pm SD) concentrations of major ions and ratios of different sources of low salinity well water $\left(T_{1}-T_{4}\right)$ and seawater $\left(T_{m}\right)$ throughout culture period / Media $( \pm D E)$ de las concentraciones y proporciones de los iones principales de las diferentes fuentes de agua de baja salinidad $\left(\mathrm{T}_{1}-\mathrm{T}_{4}\right)$ y el agua de mar $\left(\mathrm{T}_{\mathrm{m}}\right)$ a lo largo período de cultivo

\begin{tabular}{|c|c|c|c|c|c|c|}
\hline & \multirow{2}{*}{ Ions $\left(\mathrm{mg} \mathrm{L}^{-1}\right)$} & \multicolumn{5}{|c|}{ Water source (Treatments) } \\
\hline & & $\mathrm{T}_{1}$ & $\mathrm{~T}_{2}$ & $\mathrm{~T}_{3}$ & $\mathrm{~T}_{4}$ & $\mathrm{~T}_{\mathrm{m}} *$ \\
\hline \multicolumn{7}{|l|}{ Anions } \\
\hline & Bicarbonates & $303.4 \pm 50.8$ & $296.0 \pm 30.5$ & $309.2 \pm 40.6$ & $333.6 \pm 27.6$ & 142 \\
\hline & Chloride & $27.0 \pm 7.3^{\mathrm{a}}$ & $120.3 \pm 21.8^{\mathrm{c}}$ & $42.1 \pm 10.2^{b}$ & $122.5 \pm 26.1^{\mathrm{c}}$ & 19,000 \\
\hline & Sulfate & $65.4 \pm 13.1^{\mathrm{a}}$ & $196.1 \pm 33.4^{b}$ & $50.4 \pm 17.4^{\mathrm{a}}$ & $53.0 \pm 10.2^{\mathrm{a}}$ & 2,700 \\
\hline \multicolumn{7}{|l|}{ Cations } \\
\hline & Calcium & $56.8 \pm 17.4^{\mathrm{b}}$ & $198.5 \pm 46.4^{\mathrm{d}}$ & $34.0 \pm 8.7^{\mathrm{a}}$ & $85.6 \pm 11.6^{\mathrm{c}}$ & 400 \\
\hline & Magnesium & $14.7 \pm 4.4^{\mathrm{a}}$ & $137.9 \pm 27.6^{\mathrm{c}}$ & $40.6 \pm 13.1^{b}$ & $53.8 \pm 17.4^{b}$ & 1,360 \\
\hline & Sodium & $142.2 \pm 31.9^{b}$ & $48.7 \pm 11.6^{\mathrm{a}}$ & $124.8 \pm 24.7^{\mathrm{b}}$ & $159.0 \pm 27.6^{\mathrm{b}}$ & 10,500 \\
\hline & Potassium & $4.7 \pm 2.2^{\mathrm{c}}$ & $6.8 \pm 3.1^{\mathrm{c}}$ & $0.77 \pm 0.3^{\mathrm{a}}$ & $2.08 \pm 0.7^{b}$ & 370 \\
\hline \multicolumn{7}{|l|}{ Ratios } \\
\hline & $\mathrm{Na} / \mathrm{K}$ & $30.9: 1^{b}$ & $7.4: 1^{\mathrm{a}}$ & $162.5: 1^{d}$ & $76.3: 1^{\mathrm{c}}$ & $28.3: 1$ \\
\hline & $\mathrm{Ca} / \mathrm{K}$ & $12.3: 1^{\mathrm{a}}$ & $29.3: 1^{b}$ & $44.1: 1^{\mathrm{b}}$ & $41.4: 1^{b}$ & $1.08: 1$ \\
\hline & $\mathrm{Mg} / \mathrm{Ca}$ & $0.26: 1^{\mathrm{a}}$ & $0.69: 1^{b}$ & $1.19: 1^{b}$ & $0.63: 1^{\mathrm{a}}$ & $3.4: 1$ \\
\hline & $\mathrm{Mg} / \mathrm{K}$ & $3.1: 1^{\mathrm{a}}$ & $20.1: 1^{b}$ & $52.5: 1^{\mathrm{c}}$ & $25.5: 1^{\mathrm{b}}$ & $3.6: 1$ \\
\hline
\end{tabular}

Different superscripts letters in row indicate significant differences $(P<0.05)$

Water Source: $\left(\mathrm{T}_{1}\right) 25.43^{\circ} \mathrm{N}, 108.44^{\circ} \mathrm{W} ;\left(\mathrm{T}_{2}\right) 25.48^{\circ} \mathrm{N}, 108.37^{\circ} \mathrm{W} ;\left(\mathrm{T}_{3}\right) 25.60^{\circ} \mathrm{N}, 108.40^{\circ} \mathrm{W} ;\left(\mathrm{T}_{4}\right) 25.64^{\circ} \mathrm{N}, 108.51^{\circ} \mathrm{W}$ and seawater $\left(\mathrm{T}_{\mathrm{m}}\right)$ at $25.303^{\circ} \mathrm{N}, 108.533^{\circ} \mathrm{W} .{ }^{*}$ Goldberg, 1963 
During both the acclimation and study (150 organism $\mathrm{m}^{-2}$ ), organisms were fed with commercial food (35\% protein, Ralston Purina ration) 3 times a day (08:00, 12:00 and 16:00 h). The feeding rates for each group of organisms were weekly adjusted in relation to the amount of uneaten food (Cuadros \& Beltrame 1998). The feeding rates started at $18 \%$ of the biomass estimated of PL and progressively reduced to $2 \%$ when the organism has reached an average weight of about $12 \mathrm{~g}$.

\section{WATER QUALITY AND MAJOR ION ANALYSES}

Temperature $\left({ }^{\circ} \mathrm{C}\right)$, dissolved oxygen (DO, $\left.\mathrm{mg} \mathrm{L}^{-1}\right)$, and $\mathrm{pH}$ were recorded daily at 08:00 and 16:00 $\mathrm{h}$ using a standard mercury thermometer, a YSI 55 oxygen meter (Yellow Springs Instrument, Yellow Springs, OH, USA) and a potentiometer Hanna 213, respectively. Salinity was measured using a YSI 556 multi-parameter equipped with a conductivity-salinity probe (YSI ProDSS Multiparameter, Yellow Springs, Ohio, USA); additionally, it was corroborated using the criteria of Boyd et al. (2002). Every two weeks water samples were taken from each of the experimental units to analyze the concentration of nitrite $\left(\mathrm{N}-\mathrm{NO}_{2}{ }^{-}\right)$, nitrate $\left(\mathrm{N}-\mathrm{NO}_{3}{ }^{-}\right)$, total ammonia- $\mathrm{N}\left(\mathrm{N}-\mathrm{NH}_{3}\right)$ and phosphate $\left(\mathrm{PO}_{4}-\mathrm{P}\right)$ with the methods described by Arredondo-Figueroa \& Ponce-Palafox (1998).

Twice a monthly $500 \mathrm{ml}$ of water of each treatment were transported to a certified laboratory by the Mexican Federal Authorities (CNA Reg. No. CAN-GSCA-440), to analyze the concentration of major ions: bicarbonate $\left(\mathrm{HCO}_{3}^{-}\right)$, chloride $\left(\mathrm{Cl}^{-}\right)$, sulfate $\left(\mathrm{SO}_{4}^{2-}\right)$, calcium $\left(\mathrm{Ca}^{2+}\right)$, magnesium $\left(\mathrm{Mg}^{2+}\right)$, potassium $\left(\mathrm{K}^{+}\right)$and sodium $\left(\mathrm{Na}^{+}\right)$, using standard protocols described by Clesceri et al. (1998).

\section{Growth, LENGTH-WEIGHT RELATIONSHIP, CONDITION FACTOR AND SURVIVAL}

Weekly, 50 shrimp were collected randomly from each treatment, to record length $(\mathrm{mm})$ and weight $(\mathrm{g})$. Total length of shrimp (rostrum to telson distance) was measured by means of an ichthyometer ( $\pm 1 \mathrm{~mm}$, Aquatic FMB2, Aquatic Eco-Systems FL, USA) and weight was recorded using a digital scale $( \pm$ $0.01 \mathrm{~g}$, Ohaus IL, USA).

The information obtained was used to calculate the lengthweight relationship of the organisms from each treatment, using a potential model $\left(\mathrm{W}_{\mathrm{i}}=\mathrm{a} \mathrm{TL}_{\mathrm{i}}^{\mathrm{b}}\right)$, where $\mathrm{i}=$ treatment, $\mathrm{Wi}=$ weight $(\mathrm{g}), \mathrm{TLi}=$ total length $(\mathrm{mm}), \mathrm{a}=$ proportionality constant and $\mathrm{b}$ $=$ exponent of the equation.

The Fulton's equation (Ricker 1979, Chow \& Sandifer 1991) was used to determine the condition factor of each group:

$$
\mathrm{CF}_{\mathrm{i}}=\frac{\overline{\mathrm{W}}_{\mathrm{i}}}{\overline{\mathrm{TL}}^{3}} 10^{5}
$$

where $\mathrm{CFi}=$ condition factor for treatment $\mathrm{i}, \overline{\mathrm{W}}_{\mathrm{i}}=$ average weight (g) and $\overline{\mathrm{TL}}=$ average total length $(\mathrm{mm})$.

The experiment concluded after 133 days at which time all shrimp from each tank were harvested, measured (length and weight), and counted to calculate survival, growth ( $\mathrm{g}$ ), production $\left(\mathrm{kg} \mathrm{m}^{-2}\right)$ and feed conversion rate (FCR) were estimated.

\section{Statistical analysis}

Data was analyzed to determine whether there were significant differences between the treatments in growth, survival, production, water quality, and concentration of major ions. They were analyzed using a one-way variance test. Comparisons were made between treatments using Student-Newman-Keuls test. Data are expressed as mean \pm standard deviation.

A non-linear regression analysis was used to determine the length-weight relationship. The curves potential resulting from each treatment were compared with one-way analysis of covariance (ANCOVA) and a posteriori Tukey test. The statistical significance of the exponent from equation (b) was analyzed using the function proposed by Pauly (1984):

$$
\hat{\mathrm{t}}=\frac{\text { s.d. }(\mathrm{x})}{\text { s.d. }(y)} \frac{\left|\mathrm{b}_{\mathrm{i}}-3\right|}{\sqrt[2]{1-\mathrm{r}^{2}}} \sqrt[2]{\mathrm{n}_{\mathrm{i}}-2}
$$

where $\hat{t}$ is the t-student statistic, s. d. (x) and (y) are the standard deviation for $\mathrm{TL}_{\mathrm{i}}$ and $\mathrm{W}_{\mathrm{i}}$ of each treatment, $\mathrm{n}_{\mathrm{i}}$ is the number of recorded organisms, $b_{i}$ is the fitted value of $b$ for treatment, and $r^{2}$ is the coefficient of determination. Statistical significance was $\alpha \leq 0.05$.

\section{ResUlts}

\section{WATER QUALITY}

During the experimental work, there were no significant differences between water quality variables, except for salinity $(P>0.05$, Fig. 1). The average temperature, $\mathrm{DO}$ and $\mathrm{pH}$ were $28.5^{\circ} \mathrm{C}, 5.9 \mathrm{mg} \mathrm{L}^{-1}$ and 8.0, respectively(Fig. 1). The minimum and maximum concentrations of total $\mathrm{N}_{-} \mathrm{NH}_{3}$ ranged from 0.26 to $0.31 \mathrm{mg} \mathrm{L}^{-1}, \mathrm{~N}-\mathrm{NO}_{2}\left(0.28\right.$ to $\left.0.32 \mathrm{mg} \mathrm{L}^{-1}\right), \mathrm{N}_{-} \mathrm{NO}_{3}(0.73$ to $0.77 \mathrm{mg} \mathrm{L}^{-1}$ ) and $\mathrm{PO}_{4}-\mathrm{P}\left(1.5\right.$ to $1.7 \mathrm{mg} \mathrm{L}^{-1}$ ), respectively (Fig. $2)$. The salinity of each treatment of the different well water source ranged from 1.1 to $1.5 \mathrm{~g} \mathrm{~L}^{-1}$, while the control group $\left(\mathrm{T}_{\mathrm{m}}\right)$ remained at an average of $34.0 \mathrm{~g} \mathrm{~L}^{-1}$, presenting significant differences between treatments: $\mathrm{T}_{1}-\mathrm{T}_{3}$ with $\mathrm{T}_{2}-\mathrm{T}_{4}$ and both with $\mathrm{T}_{\mathrm{m}}(P<0.05$; Fig. 1d). 


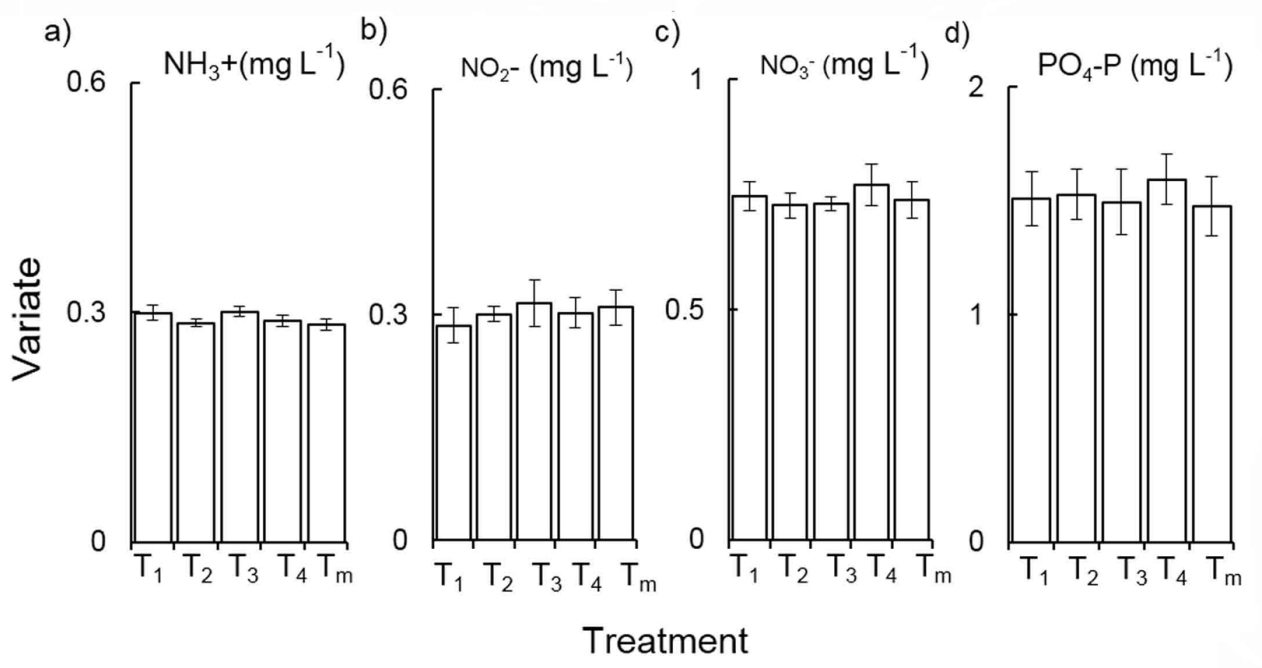

Figure 2. Mean ( \pm SD) nitrateN and phosphateP concentration in water from different sources of low salinity well water and seawater (control) throughout culture period. Water sources: $\left(T_{1}\right) 25.43^{\circ} \mathrm{N}, 108.44^{\circ} \mathrm{W} ;\left(\mathrm{T}_{2}\right) 25.48^{\circ} \mathrm{N}, 108.37^{\circ} \mathrm{W} ;\left(\mathrm{T}_{3}\right) 25.60^{\circ} \mathrm{N}, 108.40^{\circ} \mathrm{W} ;\left(\mathrm{T}_{4}\right) 25.64^{\circ} \mathrm{N}, 108.51^{\circ} \mathrm{W}$ and $\mathrm{T}_{\mathrm{m}}$, seawater at $25.303^{\circ} \mathrm{N}, 108.533^{\circ} \mathrm{W} /$ Concentración media ( $\pm \mathrm{DE}$ ) de nitrato- $\mathrm{N}$ y fostato-P en agua de pozo de diferente origen con baja salinidad y del agua de mar (control) a lo largo período de cultivo. Los pozos de agua se localizaron: $\left(\mathrm{T}_{1}\right) 25,43^{\circ} \mathrm{N}, 108,44^{\circ} \mathrm{O} ;\left(\mathrm{T}_{2}\right) 25,48^{\circ} \mathrm{N}, 108,37^{\circ} \mathrm{O} ;\left(\mathrm{T}_{3}\right) 25,60^{\circ} \mathrm{N}$, $108, .40^{\circ} \mathrm{O} ;\left(\mathrm{T}_{4}\right) 25,64^{\circ} \mathrm{N}, 108,51^{\circ} \mathrm{O}$ y $\left(\mathrm{T}_{\mathrm{m}}\right)$ agua de mar en $25,303^{\circ} \mathrm{N}, 108,533^{\circ} \mathrm{O}$

\section{MAJOR IONS CONCENTRATIONS AND RATIOS}

All treatments of low salinity well water had values of bicarbonate $\left(\mathrm{HCO}_{3}^{-}\right)$over $296.0 \pm 30.5 \mathrm{mg} \mathrm{L}^{-1}\left(\mathrm{~T}_{1}\right)$ and were higher than in the control group (sea water, $\mathrm{T}_{\mathrm{m}}$ ) $=142 \mathrm{mg} \mathrm{L}^{-1}$ (Table 1). Chloride concentration $\left(\mathrm{Cl}^{-}\right)$was between $27.0 \pm$ $7.3\left(\mathrm{~T}_{1}\right)$ to $122.5 \pm 26.1 \mathrm{mg} \mathrm{L}^{-1}\left(\mathrm{~T}_{2}\right)$, all water source was different (Table 1). In all the following cases: Calcium $\left(\mathrm{Ca}^{2+}\right)$, magnesium $\left(\mathrm{Mg}^{2+}\right)$, sodium $\left(\mathrm{Na}^{+}\right)$, potassium $\left(\mathrm{K}^{+}\right)$and sulfate $\left(\mathrm{SO}_{4}^{2-}\right)$ (Table 1) the concentrations were lower than $\mathrm{T}_{\mathrm{m}}$, all showing significant statistically differences $(P<0.05)$.

The ionic ratios for $\mathrm{Na} / \mathrm{K}$ at $\mathrm{T}_{1}, \mathrm{~T}_{3}$ and $\mathrm{T}_{4}$ were highest that $\mathrm{T}_{\mathrm{m}}$. Ratios of $\mathrm{Mg} / \mathrm{K}$ and $\mathrm{Ca} / \mathrm{K}$ were higher in all treatment of well water; conversely, $\mathrm{T}_{\mathrm{m}}$ showed higher ratios of $\mathrm{Mg} / \mathrm{Ca}$ than the others (Table 1).

\section{GrowTH, SURVIVAL AND PRODUCTION}

Higher values of weight $(13.3 \pm 0.61 \mathrm{~g})$, survival $(84.6 \pm 4.1 \%)$ and production $\left(1.70 \pm 0.18 \mathrm{~kg} \mathrm{~m}^{-2}\right)$ were recorded in $\mathrm{T}_{\mathrm{m}}$, followed for $\mathrm{T}_{1}$ for the same zootechnical parameters (Table $2)$. The lowest values of weight $\left(\mathrm{T}_{3}=10.8 \pm 1.05 \mathrm{~g}\right)$, survival $\left(\mathrm{T}_{4}=76.35 \pm 3.69 \%\right)$ and production $\left(\mathrm{T}_{3}\right.$ and $\mathrm{T}_{4}=1.25 \mathrm{~kg} \mathrm{~m}^{-}$ ${ }^{2}$ ) occurred in different well water treatments (Table 2 ). There were significant differences between the final weight $\left(\mathrm{F}_{(4,1841)}=\right.$ 4.28; $P<0.05)$ and production $\left(\mathrm{F}_{(4,14)}=7.28 ; \mathrm{P}<0.05\right)$ of treatments $\mathrm{T}_{2}, \mathrm{~T}_{3}$ and $\mathrm{T}_{4}$ in relation to $\mathrm{T}_{1}$ and $\mathrm{T}_{\mathrm{m}}$ (Table 2 ).

\section{LENGTH-WEIGHT RELATIONSHIP AND CONDITION FACTOR}

The coefficients of determination $\left(\mathrm{R}^{2}\right)$ obtained in this study ranged between 0.95 and 0.99 , indicating that the potential model used was adequate for the length-weight relationship (Fig. 3 , Table 3). The greater exponent (b) appeared in $\mathrm{T}_{3}(3.151)$, followed by $\mathrm{T}_{\mathrm{m}}$ (3.046) and $\mathrm{T}_{1}$ (3.012). ANCOVA analysis determined that the slopes of the potential models for the lengthweight relationship were significantly different between treatments $(\mathrm{F}=21.2 ; P<0.05)$. The highest condition factor occurred in farmed shrimp with $\mathrm{T}_{1}(0.711)$ and $\mathrm{T}_{\mathrm{m}}(0.700)$, both were isometric and based on $\hat{\mathrm{t}}$, there were no different from 3 ( $t=1.96 P<0.05$, Table 3$)$. Condition factor values at treatments $T_{2}, T_{3}$ and $T_{4}$ were the lowest for shrimp culture; the slopes differed from 3 , regarding the statistic (Table 3), and were consequently allometric.

\section{Discussion}

\section{WATER QUALITY}

The water quality variables $\left(\mathrm{T}, \mathrm{DO}, \mathrm{pH}, \mathrm{N}-\mathrm{NO}_{2}{ }^{-}, \mathrm{N}_{-} \mathrm{NO}_{3}^{-}, \mathrm{N}-\right.$ $\mathrm{NH}_{3}$ and $\mathrm{PO}_{4}-\mathrm{P}$ ) remained at levels appropriate for the shrimp Litopenaeus vannamei, as reported by other authors (Arredondo-Figueroa \& Ponce-Palafox 1998, Atwood et al. 2003, Saoud et al. 2003) and the temperature $\left(28^{\circ} \mathrm{C}\right.$, Fig. 1) was on the termal preferendum of $27-30^{\circ} \mathrm{C}$ for juvenile shrimps (Ponce-Palafox et al. 1997, Hernández et al. 2006). 
Table 2. Mean $( \pm S D)$ values of the indicators of $L$. vannamei reared in 4 different sources of low salinity well water and seaw ater (control) using $\mathrm{PL}_{25}$ socked at density of $\mathbf{1 5 0}$ shrimp $\mathbf{~ m}^{-2}$ for $\mathbf{1 3 3}$ days / Media $( \pm D E)$ de los indicadores de $L$. vannamei cultivados en 4 diferentes fuentes de agua de baja salinidad y agua de mar (control) utilizando $\mathrm{PL}_{25}$ a una densidad de 150 camarones $\mathrm{m}^{-2}$ por 133 días de cultivo

\begin{tabular}{cccccc}
\hline $\begin{array}{c}\text { Treatment } \\
\text { (Water source) }\end{array}$ & $\begin{array}{c}\text { Initial weight } \\
(\mathrm{g})\end{array}$ & $\begin{array}{c}\text { Final weight } \\
(\mathrm{g})\end{array}$ & FCR & Survival (\%) & Crop $\left(\mathrm{Kg} \mathrm{m}^{-2}\right)$ \\
\hline $\mathrm{T}_{1}$ & $0.013 \pm 0.0013$ & $12.8^{\mathrm{b}} \pm 0.93$ & $1.55 \pm 0.24$ & $78.4^{\mathrm{a}} \pm 3.7$ & $1.50^{\mathrm{b}} \pm 0.18$ \\
$\mathrm{~T}_{2}$ & $0.014 \pm 0.0012$ & $11.6^{\mathrm{a}} \pm 1.10$ & $1.71 \pm 0.23$ & $77.6^{\mathrm{a}} \pm 3.4$ & $1.31^{\mathrm{a}} \pm 0.20$ \\
$\mathrm{~T}_{3}$ & $0.012 \pm 0.0013$ & $10.8^{\mathrm{a}} \pm 1.05$ & $1.78 \pm 0.15$ & $78.6^{\mathrm{a}} \pm 4.3$ & $1.25^{\mathrm{a}} \pm 0.10$ \\
$\mathrm{~T}_{4}$ & $0.013 \pm 0.0011$ & $11.2^{\mathrm{a}} \pm 0.91$ & $1.68 \pm 0.19$ & $76.4^{\mathrm{a}} \pm 3.7$ & $1.25^{\mathrm{a}} \pm 0.21$ \\
$\mathrm{~T}_{\mathrm{m}}$ & $0.012 \pm 0.0012$ & $13.3^{\mathrm{b}} \pm 0.61$ & $1.58 \pm 0.10$ & $84.6^{\mathrm{b}} \pm 4.1$ & $1.70^{\mathrm{b}} \pm 0.18$ \\
\hline
\end{tabular}

FCR. Feed Conversion Rate

Different superscripts letters within rows indicate significant differences $(P<0.05)$

Water source: $\left(\mathrm{T}_{1}\right) 25.43^{\circ} \mathrm{N}, 108.44^{\circ} \mathrm{W} ;\left(\mathrm{T}_{2}\right) 25.48^{\circ} \mathrm{N}, 108.37^{\circ} \mathrm{W} ;\left(\mathrm{T}_{3}\right) 25.60^{\circ} \mathrm{N}, 108.40^{\circ} \mathrm{W}$ and $\left(\mathrm{T}_{4}\right)$ at $25.64^{\circ} \mathrm{N}$, $108.51^{\circ} \mathrm{W}$ and seawater $\left(\mathrm{T}_{\mathrm{m}}\right) 25.303^{\circ} \mathrm{N}, 108.533^{\circ} \mathrm{W}$
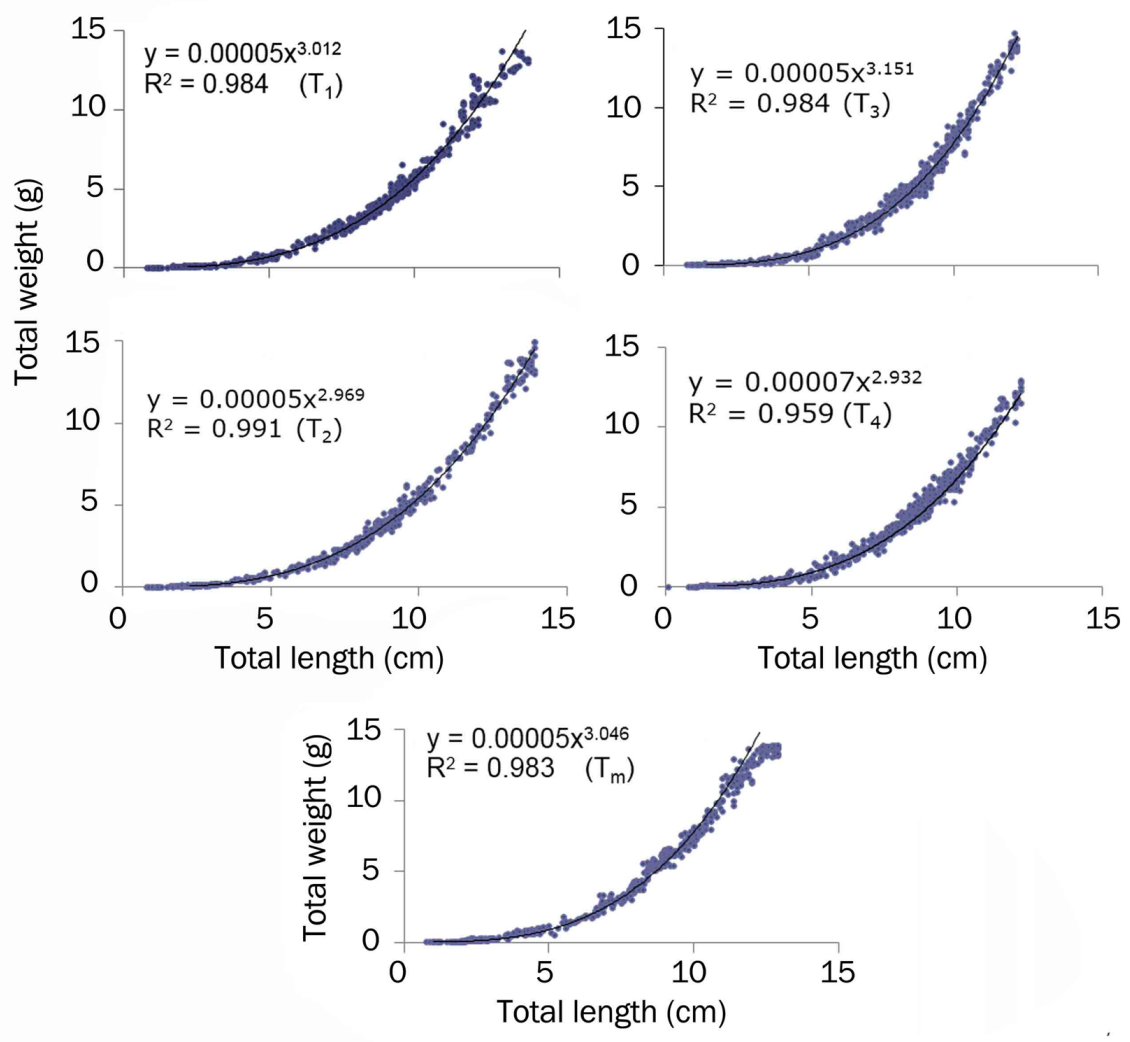

Figure 3. Length-weight relationship for white shrimp grown, using $\mathrm{PL}_{25}$ stocked at density of 150 shrimp m-2 by 133 days. Water source: $\left(\mathrm{T}_{1}\right)$ $25.43^{\circ} \mathrm{N}, 108.44^{\circ} \mathrm{W} ;\left(T_{2}\right) 25.48^{\circ} \mathrm{N}, 108.37^{\circ} \mathrm{W} ;\left(\mathrm{T}_{3}\right) 25.60^{\circ} \mathrm{N}, 108.40^{\circ} \mathrm{W}$ y $\left(T_{4}\right) 25.64^{\circ} \mathrm{N}, 108.51^{\circ} \mathrm{W}$ and $\left(\mathrm{T}_{\mathrm{m}}\right)$ seawater at $25.303^{\circ} \mathrm{N}, 108.533^{\circ} \mathrm{W}$. Each circle represents an observation / Relación talla-peso para camarón blanco cultivado, usando $\mathrm{PL}_{25}$ y sembrado a densidad de 150 camarones $\mathrm{m}^{-2}$ durante 133 días. Los pozos de agua se localizan: $\left(T_{1}\right) 25,43^{\circ} \mathrm{N}, 108,44^{\circ} \mathrm{O} ;\left(T_{2}\right) 25,48^{\circ} \mathrm{N}, 108,37^{\circ} \mathrm{O} ;\left(\mathrm{T}_{3}\right) 25,60^{\circ} \mathrm{N}, 108,40^{\circ} \mathrm{O} ;\left(\mathrm{T}_{4}\right)$ $25,64^{\circ} \mathrm{N}, 108,51^{\circ} \mathrm{O}$ y $\left(\mathrm{T}_{\mathrm{m}}\right)$ agua de mar en $25,303^{\circ} \mathrm{N}, 108,533^{\circ} \mathrm{O}$. Cada círculo representa una observación 
Table 3. Regression estimates (b) for length-weight and condition factor (CF) of $L$. vannamei reared in 4 different sources of low salinity well water and seawater (Control) using $\mathrm{PL}_{25}$ socked at density of $\mathbf{1 5 0}$ shrimp $\mathbf{m}^{-2}$ by $\mathbf{1 3 3}$ days / Valores de regresión (b) para la longitud-peso y factor de condición (CF) de L. vannamei cultivado en 4 diferentes fuentes de agua de baja salinidad y agua de mar (control) utilizando $\mathrm{PL}_{25}$ una densidad de 150 camarones $\mathrm{m}^{-2}$ por 133 días

\begin{tabular}{ccccccc}
\hline $\begin{array}{c}\text { Treatment } \\
\text { water source }\end{array}$ & Coefficient $(b)$ & $R^{2}$ & S.D. $(y)$ & S.D. $(x)$ & $\begin{array}{c}\text { Condition } \\
\text { factor (CF) }\end{array}$ & ${ }^{*} \hat{t}$ \\
\hline $\mathrm{T}_{1}$ & 3.012 & 0.984 & 1.06 & 0.47 & 0.711 & 1.017 \\
$\mathrm{~T}_{2}$ & 2.969 & 0.991 & 1.51 & 0.58 & 0.644 & 2.869 \\
$\mathrm{~T}_{3}$ & 3.151 & 0.984 & 4.36 & 0.84 & 0.495 & 5.677 \\
$\mathrm{~T}_{4}$ & 2.932 & 0.959 & 2.02 & 0.85 & 0.598 & 3.385 \\
$\mathrm{~T}_{\mathrm{m}}$ & 3.046 & 0.983 & 1.85 & 0.45 & 0.700 & 1.959 \\
\hline
\end{tabular}

${ }^{*} \hat{t}$ is the $t$-student statistic. S.D. (x) and (y) are the standard deviation for final total length $T L_{i}$ and weight $W_{i}$ of each treatment. Water source: $\left(\mathrm{T}_{1}\right) 25.43^{\circ} \mathrm{N}, 108.44^{\circ} \mathrm{W} ; 25.48^{\circ} \mathrm{N}, 108.37^{\circ} \mathrm{W} ;\left(\mathrm{T}_{3}\right) 25.60^{\circ} \mathrm{N}, 108.40^{\circ} \mathrm{W}$ and $\left(\mathrm{T}_{4}\right)$ at $25.64^{\circ} \mathrm{N}, 108.51^{\circ} \mathrm{W}$ and seawater $\left(\mathrm{T}_{\mathrm{m}}\right)$ at $25.303^{\circ} \mathrm{N}, 108.533^{\circ} \mathrm{W}$

Temperature is an important factor that influence growth rates of penaeid shrimp (Tsuzuki et al. 2000). In addition, the nitrogen compounds, for juvenile L. vannamei grown in water of $2 \mathrm{~g} \mathrm{~L}^{-}$ ${ }^{1}$ of salinity (Gross et al. 2004) suggest a safe concentration for shrimp production in ponds less than $0.45 \mathrm{mg} \mathrm{L}^{-1} \mathrm{NO}_{2}-\mathrm{N}$. In this work, shrimp exposed to nitrite and ammonia concentration of $3 \mathrm{mg} \mathrm{L}^{-1}$ combined with low chloride for long time could reduce their growth and affect their survival.

\section{GrowTH, SURVIVAL AND PRODUCTION}

Growth rates of $0.61 \mathrm{~g} \mathrm{week}^{-1}$ at a stocked density of 150 organism $\mathrm{m}^{-2}$ were recorded for the groups, while $\mathrm{T}_{\mathrm{m}}$ reached a growth rate of $0.67 \mathrm{~g} \mathrm{week}^{-1}$. In nature, this species is able to grow at $1.4 \mathrm{~g}$ week $^{-1}$ at densities of 2-3 shrimp m ${ }^{-2}$ (Menz \& Blake 1980 fide Wyban \& Sweeney 1989). There were significant differences in growth rates of farmed shrimp in $\mathrm{T}_{1}$ with the other different ionic profile treatments. The slower growth in $\mathrm{T}_{3}$ was obtained $\left(0.57 \mathrm{~g}\right.$ week $\left.^{-1}\right)$ where concentrations of potassium $\left(0.58 \mathrm{mg} \mathrm{L}^{-1}\right)$ and calcium $\left(28.00 \mathrm{mg} \mathrm{L}^{-1}\right)$ were lower than other treatments. A trend of greater shrimp growth was observed within the ratio values of $\mathrm{Na} / \mathrm{K}\left(\mathrm{T}_{1}=30.9\right)$ and $\mathrm{Mg} / \mathrm{K}\left(\mathrm{T}_{1}=3.1\right)$, which were similar to that of seawater $\left(\mathrm{T}_{\mathrm{m}}\right.$; $\mathrm{Na} / \mathrm{K}=28.1$ and $\mathrm{Mg} / \mathrm{K}=3.6$ ). The water ionic profile may vary from each well in different areas (Boyd \& Thunjai 2003). This indicates that to grow L. vanname $i$ with well water it is important to account for ionic ratios and water salinity values (Saoud et al. 2003, Esparza-Leal et al. 2010). Other indicator is estimating acceptable concentrations of individual ions for brackish water shrimp culture, proposed by Boyd et al. (2002); in this case, any treatment was similar to that estimate of seawater. However, the minimum acceptable concentration of total alkalinity as bicarbonate at all cases was over about 300 mg L ${ }^{-1}$ (Boyd \& Tucker 1998); this condition avoids shrimp has difficulty molting.
Shrimp culture with different source of well water has a mean survival of $77 \%$. Regardless of salinity content, the ionic water profile is a variable that significantly influences the survival of shrimp (Davis et al. 2002, Saoud et al. 2003, Zhu et al. 2004). Farmed shrimp with different ion profiles on water achieved better growth and survival in the $\mathrm{Na} / \mathrm{K}$ ratio similar to seawater (Roy 2006). In several experiments, Roy et al. (2007) observed better survival and average individual weight of postlarvae, when the culture water approximates to $\mathrm{Na} / \mathrm{K}$ ratio of $28: 1$, similar to seawater. Also, Roy et al. (2007) found that growing juvenile shrimp in reconstituted seawater $\left(4 \mathrm{~g} \mathrm{~L}^{-1}\right)$ in the treatment of 40 $\mathrm{mg} \mathrm{K} \mathrm{L}^{-1}$ sustaining a significantly higher weight gain compared to low $\mathrm{K}^{+}$concentrations. An additional experiment, reference water (control) and treatment of $40 \mathrm{mg} \mathrm{K}^{+} \mathrm{L}^{-1}$ maintained $\mathrm{Na} /$ $\mathrm{K}$ ratios of 29:1 and 30:1, respectively. In concordance with Roy et al. (2010) the adequate concentrations of essential ions, including potassium $\left(\mathrm{K}^{+}\right)$and magnesium $\left(\mathrm{Mg}^{2+}\right)$, support better growth and survival of shrimp. Perez-Velazquez et al. (2012) conducted an experiment with water temperature of 26 and $30^{\circ} \mathrm{C}$ and $\mathrm{Na}^{+} / \mathrm{K}^{+}$ratios of 40,80 and $120: 1$. Growth of shrimp was significantly higher at the $\mathrm{Na}^{+} / \mathrm{K}^{+}$ratio of 40:1 and shrimp survival were no affected by any $\mathrm{Na}^{+} / \mathrm{K}^{+}$ratio.

Final mean weight of shrimp on treatment 1 and seawater $\left(\mathrm{T}_{\mathrm{m}}\right)$ was higher and there were significant differences in the production of shrimp within treatments. Observed by Al-Ameeri \& Cruz (2006) and according to Wang et al. (1998), mean final sizes of shrimp have a tendency to decrease with increase stocking density and until the carrying capacity of the system is reached. Seawater treatment $\left(\mathrm{T}_{\mathrm{m}}\right)$ presented maximum biomass by the end of the experimental run resulting in a higher production per unit area, because higher survival and means final body weight. 


\section{LENGTH-WEIGHT RELATIONSHIP AND CONDITION FACTOR}

The potential relationship of length-weight was similar in all treatments of this study and corresponds to that reported for Penaeid species (Dall et al. 1990). Reports indicate that when coefficient $b$ is equal to 3 , isometric growth is observed. Wootton (1992) reported that growth is positive-allometric when the weight of organisms increases more than the length $(b>3)$ and negative-allometric when the length is greater than the weight $(b<3)$. In this study the organisms of treatments $\mathrm{T}_{1}$ and $\mathrm{T}_{\mathrm{m}}$ showed isometric growth. While for organisms of treatments $\mathrm{T}_{2}(b=2.969)$ and $\mathrm{T}_{4}(b=2.932)$, the growth revealed to be negative-allometric. $\mathrm{T}_{3}$ proved positive-allometric $(b=3.151)$. The length-weight relationship was not proportioned between cultured organisms on well water treatments, probably because of their dissimilar proportionality ion ratios that can affect the growth of organisms (Roy et al. 2007). Effect of ion ratios on growth rates could be hidden by the density effect (stocked at a density of 150 organism $\mathrm{m}^{-2}$ ), given that shrimp growth depends heavily on the latter (Murphy et al. 1991).

Growths to those organisms cultured in seawater $\left(\mathrm{T}_{\mathrm{m}}\right)$ and $\mathrm{T}_{1}$ were no different, moreover at those treatments ionic ratios for $\mathrm{Na} / \mathrm{K}$ and $\mathrm{Mg} / \mathrm{K}$ were statistically similar from seawater. Concentrations of all ions possibly enhanced survival and growth, but after using factors presented by Boyd et al. (2002) any treatment was similar with calculated concentrations. McNevin et al. (2004) assume that higher potassium concentrations were mainly responsible for superior survival and growth. In this experiment potassium in all treatments was lower that calculated to conserved proportionality at seawater (Castille \& Lawrence 1981, Ferraris et al. 1986, ParadoEstepa et al. 1987), suggesting that most important ions in osmoregulation are chloride and sodium, but the effect of these two ions was important on growth and survival when ionic ratios were near to seawater.

In this analysis, the relationship $\mathrm{Na} / \mathrm{K}\left(\mathrm{T}_{1}=30.9\right)$ and $\mathrm{Mg} / \mathrm{K}$ $\left(\mathrm{T}_{1}=3.1\right)$ in low salinity water were similar to that of seawater on conserved proportionality of ions that are considered suitable for growing shrimp. In these conditions the white shrimp can maintain the growth and survival suitable for cultivation. Shrimp cannot compensate for the ionic balance to maintain good growth rates and which consequently condition indices are lower as founded in some treatments $\left(\mathrm{T}_{4}, \mathrm{~T}_{2}\right.$ and $\left.\mathrm{T}_{3}\right)$. Also, condition of shrimp obtained in treatments of seawater $\left(\mathrm{T}_{\mathrm{m}}\right)$ and $\mathrm{T}_{1}$ was better. Shrimp culture in low salinity well water is one of multiple cause of stress for the marine shrimp L. vannamei when the ratio of ions is different from that seawater. Shrimp cultured in water of low salinity with an ionic ratio similar to that of sea water were organisms with the best development under cultivation, therefore indicating that the proportion of ions were important for growth.

\section{ACKNOWLEDGMENTS}

We would like to thank the Instituto Politécnico Nacional (SIP20151736) for providing funds for this research. The authors would like to extend thanks to the Aquapacific Hatchery for providing Litopenaeus vannamei postlarvae.

\section{LITERATURE CITED}

Al-Ameeri AA \& EM Cruz. 2006. Production and yield of Penaeus semisulcatus (de Haan) cultured at different densities. Aquaculture Research 37: 1499-1506.

Araneda M, EP Pérez \& E Gasca-Leyva. 2008. White shrimp Penaeus vannamei culture in freshwater at three densities: Condition state based on length and weight. Aquaculture 283: 13-18.

Arredondo-Figueroa JL \& JT Ponce-Palafox. 1998. Calidad del agua en acuicultura: conceptos y aplicaciones, $222 \mathrm{pp}$. AGT Editor, México.

Atwood HL, SP Young, JR Tomasso \& CL Browdy. 2003. Survival and growth of Pacific white shrimp Litopenaeus vannamei postlarvae in low salinity and mixed salt environments. Journal of the World Aquaculture Society 34: 518-523.

Boyd CE. 1989. Water quality management and aeration in shrimp farming. Fisheries and Allied Aquacultures Departmental Series 2: 1- 83. Alabama Agricultural Experiment Station, Auburn University, Auburn.

Boyd CE \& T Thunjai. 2003. Concentrations of major ions in water of inland shrimp farms in China, Ecuador, Thailand and the United States. Journal of the World Aquaculture Society 34: 524-532.

Boyd CE \& CS Tucker. 1998. Aquaculture water quality management, 700 pp. Kluwer Academic Publishers, Boston.

Boyd CE, T Thunjai \& M Boonyaratpalin. 2002. Dissolved salts in waters for inland, low salinity shrimp culture. Global Aquaculture Advocate 5: 40-45.

Castille FL \& AL Lawrence. 1981. The effect of salinity on the osmotic, sodium and chloride concentrations in the hemolymph of euryhaline shrimp of the genus Penaeus. Comparative Biochemistry and Physiology, Part A: Molecular \& Integrative Physiology 68: 75-80.

Cheng KM, CQ Hu, YN Liu, SX Zheng \& XJ Qi. 2005. Effects of dietary calcium, phosphorus and calcium/ phosphorus ratio on the growth and tissue mineralization of Litopenaeus vannamei reared in low-salinity water. Aquaculture 251:472-783.

Chow S \& PA Sandifer. 1991. Differences in growth, morphometric traits, and male sexual maturity among Pacific white shrimp, Penaeus vannamei, from different commercial hatcheries. Aquaculture 92: 165-179.

Clesceri LS, AE Greenberg \& AD Eaton. 1998. Standard methods for the examination of water and wastewater, 1325 pp. American Public Health Association, Washington. 
Cuadros W \& E Beltrame. 1998. Nuevas técnicas de alimentación con bandejas en el Brasil. Panorama Acuícola 3: 8-9.

Dall W, BJ Hill, PC Rothlisberg \& DJ Staples. 1990. The biology of the Penaeidae. Advances in Marine Biology, 489 pp. Academic Press, London.

Davis DA \& AL Lawrence. 1997. Minerals. In: D'Abramo LR, DE Conklin \& DM Akiyama (eds). Crustacean Nutrition 6: 150-163. World Aquaculture Society, Baton Rouge.

Davis DA, IP Saoud, WJ McGraw \& DB Rouse. 2002. Considerations for Litopenaeus vannamei reared in inland low salinity waters. In: Cruz-Suárez LE, D Richque-Marie, M Tapia-Salazar, MG Gaxiola-Cortés \& N Simoes (eds). Avances en nutrición acuícola, pp. 73-94, Memorias del VI Simposium Internacional de Nutrición Acuícola, 3 al 6 de septiembre del 2002, Cancún, Quintana Roo, México.

Esparza-Leal HM, JT Ponce-Palafox, EA Aragón-Noriega, JL Arredondo-Figueroa, M García-Ulloa-Gómez \& W Valenzuela-Quiñonez. 2010. Growth and performance of the whiteleg shrimp Penaeus vannamei (Boone) cultured in low-salinity water with different stocking densities and acclimation times. Aquaculture Research 41: 878-883.

Ferraris RP, FD Parado-Estepa, JM Ladja \& EG de Jesus. 1986. Effect of salinity on osmotic, chloride, total protein and calcium concentrations in the hemolymph of the prawn Penaeus monodon (Fabricius). Comparative Biochemistry and Physiology, Part A: Molecular \& Integrative Physiology 83(4): 701-708.

Godinez-Siordia DE, MC Chávez-Sánchez \& S GómezJiménez. 2011. Epicontinental aquaculture of the Pacific white shrimp, Litopenaeus vannamei (Boone, 1931). Tropical and Subtropical Agroecosystem 14: 55-62.

Goldberg ED. 1963. The oceans as a chemical system. In: Hill MN (ed). The composition of Seawater: Comparative and descriptive oceanography. The Sea: Ideas and Observations on Progress in the Study of the Seas 2: 3-25. Interscience Publisher, New York.

Gong H, DH Jiang, DV Lightner, C Collins \& D Brock. 2004. A dietary approach to improve the osmoregulatory capacity of Litopenaeus vannamei cultured in the Arizona desert. Aquaculture Nutrition 10: 227-236.

Gross A, S Abutbul \& D Zilberg. 2004. Acute and chronic effects of nitrite on white shrimp, Litopenaeus vannamei, cultured in low-salinity brackish water. Journal of the World Aquaculture Society 35(3): 315-321.

Gullian M, C Aramburu, B Sanders \& R Lope. 2010. Viability of culturing pink shrimp Farfantepenaeus duorarum in low-salinity groundwater from the Yucatan Peninsula (SE Mexico). Aquaculture 302: 202-207.

Hernández M, LF Buckle, E Palacios \& B Baron. 2006. Preferential behavior of white shrimp Litopenaeus vannamei (Boone 1931) by progressive temperature salinity simultaneus interaction. Journal of Thermal Biology 31: 565572.
Mantel LH \& LL Farmer. 1983. Osmotic and ionic regulation. In: Mantel LH (ed). Internal anatomy and physiological regulation. The Biology of Crustacea 5: 54-162. Academic Press, New York.

McGraw WJ \& J Scarpa. 2004. Mortality of freshwateracclimated Litopenaeus vannamei associated with acclimation rate, habituation period, and ionic challenge. Aquaculture 236: 285-296.

McNevin AA, CE Boyd, O Silapajarn \& K Silapajarn. 2004. Ionic supplementation of pond waters for inland culture of marine shrimp. Journal of the World Aquaculture Society 35(4): 460- 467.

Menz A \& BF Blake. 1980. Experiments on the growth of Penaeus vannamei Boone. Journal of Experimental Marine Biology and Ecology 48: 99-111.

Murphy BR, D Willis \& TA Springer. 1991. The relative weight index in fisheries management. Status and Need Fisheries 16: 30-48.

Nunes AJP \& CV Lopez. 2001. Low-salinity, inland shrimp culture in Brazil and Ecuador -economics, disease issues move farms away from coasts. Global Aquaculture Advocate 4: $62-64$

Parado-Estepa F, RP Ferraris, JM Ladja \& EG de Jesus. 1987. Responses of intermolt Penaeus indicus to large fluctuations in environmental salinity. Aquaculture 64: 175184.

Pauly D. 1984. Fish population dynamics in tropical waters: a manual for the use with programmable calculators. ICLARM, Studies and Reviews 8: 1-325. International Center for Living Aquatic Resources Management, Manila.

Pequeux A. 1995. Osmotic regulation in crustaceans. Journal of Crustacean Biology 15: 1-60.

Perez-Velazquez M, DA Davis, LA Roy \& ML GonzálezFélix. 2012. Effects of water temperature and $\mathrm{Na}+\mathrm{K}+$ ratio on physiological and production parameters of Litopenaeus vannamei reared in low salinity water. Aquaculture 342/343: 13-17.

Ponce-Palafox J, CA Martínez-Palacios \& LG Ross. 1997. The effects of salinity and temperature on the growth and survival rates of juvenile white shrimp Penaeus vannamei Boone 1931. Aquaculture 157: 107-115.

Ricker WE. 1979. Growth rates and models. In: Hoar WS, DJ Randall \& JR Brett (eds). Bioenergetics and growth. Fish Physiology 7: 677-743. Academic Press, New York.

Roy LA. 2006. Physiological and nutritional requirements for the culture of the Pacific white shrimp, Litopenaeus vannamei, in low salinity water. PhD Dissertation, Graduate Faculty of Auburn University, Alabama, 126 pp.

Roy LA, DA Davis, IP Saoud \& RP Henry. 2007. Effects of varying levels of aqueous potassium and magnesium on survival, growth, and respiration of the Pacific white shrimp, Litopenaeus vannamei, reared in low salinity waters. Aquaculture 262:461-469. 
Roy LA, DA Davis, IP Saoud, CA Boyd, HJ Pine \& CE Boyd. 2010. Shrimp culture in inland low salinity waters. Reviews in Aquaculture 2: 191-208.

Samocha TM, L Hamper, CR Emberson, AD Davis, D McIntosh, AL Lawrence \& PM Van Wyk. 2004. Production of the pacific white shrimp, Litopenaeus vanname $i$, in high-density greenhouse-enclosed raceways using low salinity groundwater. Journal of Applied Aquaculture 15: 1-19.

Saoud IP, DA Davis \& DB Rouse. 2003. Suitability studies of inland well waters for Litopenaeus vannamei culture. Aquaculture 217: 373-383.

Tsuzuki MY, RO Cavalli \& A Bianchini. 2000. The effects of temperature, age and acclimation to salinity on the survival of Farfantepenaeus paulensis postlarvae. Journal of the World Aquaculture Society 31: 459-468.
Wang JQ, D Dong, S Wang \& X Tian. 1998. Experimental studies on polyculture in closed shrimp ponds. I. Intensive polyculture of Chinese shrimp (Penaeus chinensis) with tilapia hybrids. Aquaculture 163: 11-27.

Wootton RJ. 1992. Fish ecology: tertiary level biology, 212 pp. Blackie, London.

Wyban JA \& JN Sweeney. 1989. Intensive shrimp growout trials in a round pond. Aquaculture 76: 215-225.

Zhu C, SL Dong, F Wang \& G Huang. 2004. Effects of Na/ $\mathrm{K}$ ratio in seawater on growth and energy budget of juvenile Litopenaeus vannamei. Aquaculture 234: 485-496.

Zhu C, SL Dong \& F Wang. 2006. The interaction of salinity and $\mathrm{Na} / \mathrm{K}$ ratio in seawater on growth, nutrient retention and food conversion of juvenile Litopenaeus vannamei. Journal of Shellfish Research 25: 107-112.

Received 9 May 2016 and accepted December 2016

Editor: Claudia Bustos D. 